\title{
Isolation and Expression of the Drosophila Drosulfakinin Neural Peptide Gene Product, DSK-I ${ }^{1}$
}

\author{
R. NICHOLS \\ Departments of Biological Chemistry and Biology, University of Michigan, Ann Arbor, Michigan 48109-1048
}

Received for publication January 10, 1992

The Drosophila drosulfakinin (dsk) gene encodes the cholecystokinin homologues drosulfakinin-I (DSK-I) and drosulfakinin-II (DSK-II). The naturally occurring DSKI peptide was isolated from an extract of adult flies and its sequence determined by automated Edman degradation and sequence-specific radioimmunoassay. The dsk cDNA is expressed during the larval, pupal, and adult stages of development and is an abundant adult head transcript. Sequence-specific DSK antibodies localized DSK expression in the Drosophila larval central nervous system to medial neurosecretory cells and projections that extend from the neurons anteriorly into the brain and posteriorly down the ventral ganglion. The availability of the dsk transcript, sequence-specific DSK antibodies and the application of molecular genetics provide the opportunity to elucidate the role(s) of Drosophila CCK homologues in brain structure and function. (1992 Academic Press, Inc.

\section{INTRODUCTION}

Neural peptides constitute an important class of messengers acting as transmitters, regulators, and/or hormones (1). During the past decade, an increasing number of peptides have been isolated and characterized from vertebrate neural tissue. Some of these peptides were known to be present in nonneural vertebrate tissues, as well as in lower species. The conservation of sequence, widespread distribution, and abundance of these peptides suggests that they may play important roles in neural function.

Cholecystokinin (CCK) and gastrin are members of a family of peptides that have long been recognized as gastrointestinal peptide hormones. Gut CCK and gastrin function as hormonal regulators of various digestive processes and feeding behaviors. Although originally isolated

\footnotetext{
${ }^{1}$ The drosulfakinin gene is referred to as dsk using lowercase letters since it has not been established whether the gene is dominant or recessive. The drosulfakinin peptides are designated DSK analogous to CCK and LSK peptides.
}

from the gut, CCK is now known to be one of the most abundant vertebrate brain peptides (2). Extensive studies on the possible neural function of CCK have led to numerous suggestions as to its physiological role(s). For instance, it is thought that neural CCK may be involved in feeding behavior, in mediation of painful stimuli, in modulation of dopaminergic function, and in induction of panic-like attacks $(3,4)$.

CCK-like immunoreactive materials have been identified in numerous invertebrates. Leucosulfakinin (LSK) and leucosulfakinin-II (LSK-II) peptides isolated from cockroach head share C-terminal sequence homology with CCK peptides $(5,6)$. Contraction of visceral muscle promoted by LSK peptides in cockroach hindgut and its attendant stimulation of hemolymph circulation are analogous to CCK-induced motility and increased circulation in mammalian intestine.

Analysis of the Drosophila drosulfakinin (dsk) DNA sequence suggests that two CCK-like peptides (DSK-I and DSK-II) are processed from the precursor by posttranslational processing at basic amino acid residues ( 7 , 8). Although conversion of a precursor to final products most commonly occurs at adjacent basic amino acid residues or at single arginyl residues $(9,10)$, not all of these possible cleavage sites are utilized. It appears that both primary and secondary structural features are important for determining processing sites. As a result, it is not possible to predict with certainty what the final products of processing will be solely on the basis of the deduced sequence of the precursor. Although deduction of amino acid sequence from DNA has become a common first step in predicting bioactive peptides, it is important to isolate and structurally characterize naturally occurring peptides.

FMRFamide (PheMetArgPheNH ${ }_{2}$ ) and FMRFamidecontaining peptides are widely distributed among invertebrates and share an identical - MetArgPheNH $\mathrm{N}_{2} \mathrm{C}$-terminal sequence with DSK peptides. Antiserum to FMRFamide stains a certain subset of neurons in Drosophila (11). However, since the specificity of the antiserum was to the C-terminal amino acids -ArgPheNH the immunohistochemical data cannot be interpreted unambiguously. A recent study to map the sites of 
FMRFamide expression in the Drosophila nervous system using peptide antibodies that recognize proFMRFamide and the N-terminus of DPKQDFMRFamide, a peptide encoded in proFMRFamide, localized FMRFamide-specific expression to cells in the Drosophila ventral ganglion $(12,13)$.

To begin the study of the role of Drosophila CCK homologues in brain structure and function, experiments were undertaken to isolate DSK-I and confirm its expression in neural tissue. This paper reports the structural characterization of the naturally occurring Drosophila cholecystokinin homologue, DSK-I, and its expression in neural tissue. The naturally occurring DSK-I peptide was isolated and a sequence-specific antisera was used to localize DSK-specific expression to the medial neurosecretory cells in the larval central nervous system.

\section{ME'THODS}

Production of antibody. The peptide PheAspAspTyrGlyHisMetArgPheNH ${ }_{2}$ corresponding to DSK-I was synthesized using an Applied Biosystems model 430A solid phase peptide synthesizer. The peptide was purified by preparative reversed-phase and ion exchange HPLC. The structure of the synthetic DSK-I peptide was confirmed by mass spectrometry, amino acid analysis, and automated Edman degradation. Mass was determined by fast atom bombardment mass spectrometry (FAB MS) using a Kratos MS-50 mass spectrometer. The matrix was thioglycerol and ions were detected in the positive mode and peak matching was against cesium iodide ion clusters. Amino acid analysis was done after acid hydrolysis in $6 \mathrm{~N} \mathrm{HCl}$ for $24 \mathrm{~h}$ at $110^{\circ} \mathrm{C}$ in vacuo. The hydrolysate was dried under a nitrogen stream and the analysis done on a Beckman 6300 amino acid analyzer using standard operating conditions. The synthetic peptide was sequenced on an Applied Biosystems Model 470 automated protein sequencer with on-line detection of P'TH-amino acids using standard operating conditions.

Antibody was raised in two New Zealand white rabbits to DSK-I conjugated to succinylated thyroglobulin via carbodiimide coupling (14). The initial immunization was by intradermal injections at multiple sites using a total of $1 \mathrm{mg}$ antigen emulsified in Freund's complete adjuvant. Subsequent boosts were given every 2 weeks by subcutaneous injections of $0.5 \mathrm{mg}$ antigen in Ribi adjuvant system (Ribi Immunochem Research). The titer was monitored by a solid phase dot blot assay for small peptides (15).

Because DSK and FMRFamide peptides have an identical C-terminal sequence, polyclonal antibody to DSK-I would yield ambiguous localization data. Analysis of the antisera by solid phase dot blot assay indicated that the unpurified antisera recognized both DSK-I and FMRFamide peptides. Antibody used for DSK localization studies was selected for by binding the antibudies that recognized the common $\mathrm{C}$-terminus to a FMRFamide peptide affinity column. The FMRFamide peptide affinity column capacity was three times greater than the amount of antisera applied. Antibody was passed over the column two times and antibody not bound to the column was assayed by dot blot. The unbound antibody recognized synthetic DSK-I but did not recognize FMRFamide, CCK, or neuropeptide $\mathrm{Y}$, a peptide without sequence homology; this antibody is referred to as sequence-specific DSK antibody. The antibody bound to the column was released

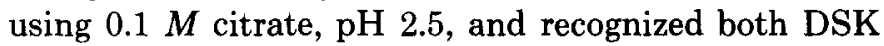
and FMRFamide peptides.

Isolation of the naturally occurring DSK-I peptide. The unpurified antibody was found suitable for a general radioimmunoassay to detect peptides containing a C-terminal-ArgPheNH ${ }_{2}$. Synthetic DSK-I was iodinated using Iodogen (Pierce) (16). Antigens were detected using a competition radioimmunoassay (17). The solid phase matrix was provided by adding Staphylococcus aureus membranes (Calbiochem). The amount of antiserum used was determined by titrating the antibody with labeled antigen to yield a strong signal. To quantitate the level of antigen in the column fractions, serial dilutions of the antigen test solution were made and a standard curve was generated for each radioimmunoassay. Each experimental and standard curve sample was done in triplicate. A typical assay included: $5-\mu \mathrm{l}$ column fraction, $20 \mu \mathrm{l}$ washed $S$. aureus membranes, $10 \mu \mathrm{l}$ antiserum diluted 1:1000, $2 \mu \mathrm{l}$ ${ }^{125}$ I-labeled DSK-I, and $185 \mu \mathrm{l}$ buffer (3\% BSA/PBS with $0.02 \%$ sodium azide). Background was determined by including a sample without labeled antigen and one without antibody.

Six hundred grams of adult $D$. melanogaster raised on standard corn meal agar media at room temperature was homogenized in methanol/water/acetic acid, 900:90:10, containing $25 \mu \mathrm{g} / \mathrm{ml}$ Pepstatin A (Bachem). The extract was centrifuged, the pellet was reextracted with acidic methanol, and the second extract was centrifuged. The supernatants were combined, freeze-dried, and washed with diethyl ether. The freeze-dried extract was suspended in $1 \mathrm{~N}$ formic acid and then applied to a Sephadex G-25 (Pharmacia) $4.5 \times 100-\mathrm{cm}$ column that had been equilibrated with $1 \mathrm{~N}$ formic acid. Two-milliliter fractions were collected and assayed for immunoreactivity as described above. Fractions from each of the two major immunoreactive peaks were combined separately, diluted and then subjected to a desalting, concentrating step using SepPak (Waters) cartridges. Peptides were eluted from the SepPak using $50 \%$ acetonitrile, $0.1 \%$ TFA with no loss of immunoreactivity observed after this desalting procedure.

The desalted fractions from the Sephadex G-25 column were diluted 3 to 1 with $5 \mathrm{~m} M$ sodium phosphate, $\mathrm{pH} 3.0$, 25\% acetonitrile and applied to a Polysulfoethyl aspartamide ion exchange column, $9.3 \mathrm{~mm} \times 20 \mathrm{~cm}$ (PolyLC) 
(18), equilibrated with Buffer A (5 $\mathrm{mM}$ sodium phosphate, $\mathrm{pH} 3.0,25 \%$ acetonitrile). The operating conditions were: Buffer A for 10 min after injection, to $20 \%$ Buffer B (200 $\mathrm{m} M$ sodium phosphate, $\mathrm{pH} 3.0,25 \%$ acetonitrile) at 80 $\mathrm{min}$, to $40 \%$ Buffer B at $90 \mathrm{~min}$, and held at $40 \%$ Buffer $\mathrm{B}$ for $5 \mathrm{~min}$ with a flow rate of $1.2 \mathrm{ml} / \mathrm{min}$. Fractions were collected on the basis of absorbance measured at $A_{225}$. Five-microliter aliquots of each fraction were analyzed by radioimmunoassay.

Immunoreactive material was further purified on a PLRPS reversed-phase column $(100 \AA), 4.6 \mathrm{~mm} \times 25 \mathrm{~cm}$ (Polymer Labs), and peptides were eluted with a linear gradient of 0 to $40 \%$ acetonitrile plus $0.1 \%$ TFA in 60 $\mathrm{min}$. The flow rate was $0.7 \mathrm{ml} / \mathrm{min}$ and fractions were collected based on absorbance measured at $A_{225}$. Fivemicroliter aliquots of each fraction collected were analyzed by radioimmunoassay. The immunoreactive material identified was frequently subjected to further purification by microbore reversed-phase HPLC and the purified material sequenced on an Applicd Biosystems Model 470 automated protein sequencer with on-line detection of PTH-amino acids using standard operating conditions.

Northern blot analysis. Total RNA from various developmental stages was isolated (19), poly $(\mathrm{A})^{+}$RNA enriched (20), and $10 \mu \mathrm{g}$ poly $(\mathrm{A})^{+} \mathrm{RNA}$ fractionated by size on a formaldehyde gel. The hybridization probe, a 780bp EcoRI-EcoRI dsk fragment containing both DSK-I and DSK-II (8), was ${ }^{32} \mathrm{P}$-labeled by nick-translation to approximately $10^{8} \mathrm{cpm} / \mu \mathrm{g}$. The gel was blotted to Nytran membrane; hybridized at $65^{\circ} \mathrm{C}, 6 \times \mathrm{SSC}, 2 \times$ Denhardt's solution, $0.5 \% \mathrm{SDS}$; washed at $65^{\circ} \mathrm{C}, 6 \times \mathrm{SSC}, 0.1 \% \mathrm{SDS}$; and exposed to Kodak XAR 5 film with one intensifying screen at $-80^{\circ} \mathrm{C}$ for 4 days.

Immunohistochemical localization of DSK peptides. Third instar larval neural tissue was dissected in cold Ringer's solution and prepared for immunohistochemistry according to White et al. (11). Whole mount preparations fixed in paraformaldehyde and washed in PBS were incubated for $2 \mathrm{~h}$ at $4^{\circ} \mathrm{C}$ with sequence-specific DSK antibody, washed extensively, and then incubated for $2 \mathrm{~h}$ at $4^{\circ} \mathrm{C}$ with FITC-labeled anti-rabbit antibody (Sigma). Controls included no antibody, no second antibody, and antibody preabsorbed for $2 \mathrm{~h}$ at $4^{\circ} \mathrm{C}$ with DSKI, FMRFamide, or CCK at concentrations of 0.1 and $0.0001 M$.

\section{RESULTS AND DISCUSSION}

Isolation of the naturally occurring Drosophila DSK-I peptide. The first step in the purification of peptides from the Drosophila homogenate was to separate an acidic methanol extract of adult flies based on size using a Sephadex G-25 column. Two major peaks of - $\mathrm{ArgPheNH} \mathrm{PH}_{2}$-like immunoreactivity were observed after gel exclusion fractionation of the Drosophila extract (Fig. 1). Since ArgPheNH ${ }_{2}$-containing peptides isolated to date and

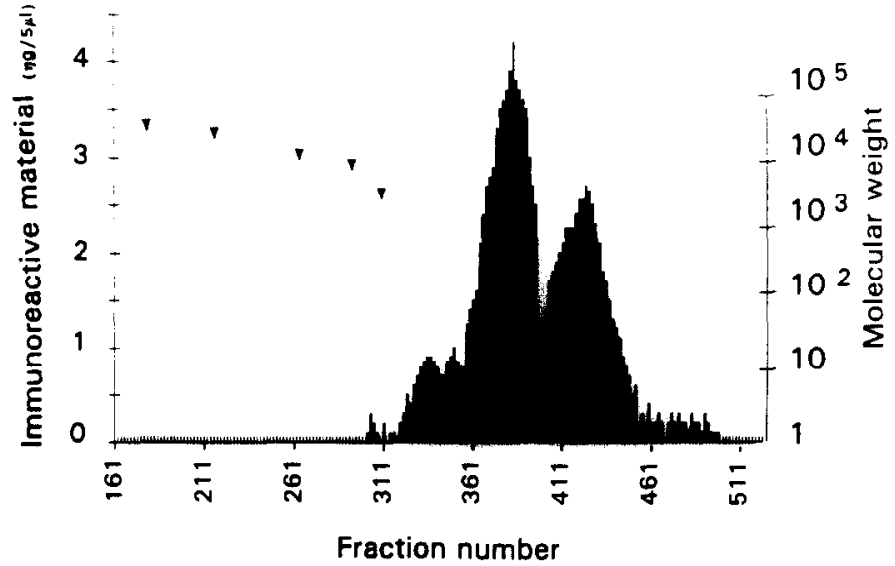

FIG. 1. Sephadex G-25 profile of Drosophila homogenate. Elution profile of acidic methanol extract of $600 \mathrm{~g}$ of adult $D$. melanogaster on Sephadex G-25 $(4.5 \times 100 \mathrm{~cm})$. Peptides were eluted from the column using $1 N$ formic acid. Two-milliliter fractions were collected at a flow rate of $35 \mathrm{ml} / \mathrm{h}$. Five-microliter aliquots of fractions 161-531 were analyzed by radioimmunoassay. No immunoreactive material was present in fractions 161-410. Void volume and salt volume correspond to fractions 161 and 531, respectively. Molecular weight standards (Sigma) are indicated by arrows: bovine serum albumin, $66,000 \mathrm{Da}$; ovalbumin, $43,000 \mathrm{Da}$; carbonic anhydrase, $29,000 \mathrm{Da}$; lysozyme, $14,300 \mathrm{Da}$; and $\beta$ chain insulin, $3200 \mathrm{Da}$.

those that can be predicted from DNA precursors are fairly similar in size, it was then necessary to take advantage of the independent physical parameters of charge and hydrophobicity to separate the structurally related peptides. Ion exchange and reversed-phase (Fig. 2) HPLC were used to further purify the immunoreactive species. The purified immunoreactive material present as a single peak in fraction 56 from the PLRPS column was further purified by microbore reversed-phase HPLC (data not shown) and subjected to automated Edman degradation which identified nine amino acid residues (Table 1). Edman sequencing does not provide information regarding the presence of a $\mathrm{C}$-terminal amide. However, the radioimmunoassay used requires a $\mathrm{C}$-terminal amide as part of the recognition site. Taken together these data identify the sequence of the peptide as PheAspAspTyrGlyHisMetArgPheNH${ }_{2}$. The sequence determined for the naturally occurring peptide is the same as the sequence of the DSK-I peptide predicted from the drosulfakinin precursor. The recovery of DSK-I from the acidic methanol extraction of $600 \mathrm{~g}$ of flies was approximately 0.18 nmol based on radioimmunoassay data.

Expression of Drosophila dsk RNA. To study dsk developmental expression, poly $(\mathrm{A})^{+}$RNA was isolated from larvae, pupae, and adult whole bodies. Northern blot analysis indicates that the dsk transcript is expressed in all three developmental stages in approximately equal amounts. In addition to isolating RNA from adult whole body, RNA was also isolated from adult head. The Northern blot data from adult head poly(A) ${ }^{+}$RNA (Fig. 3) and 


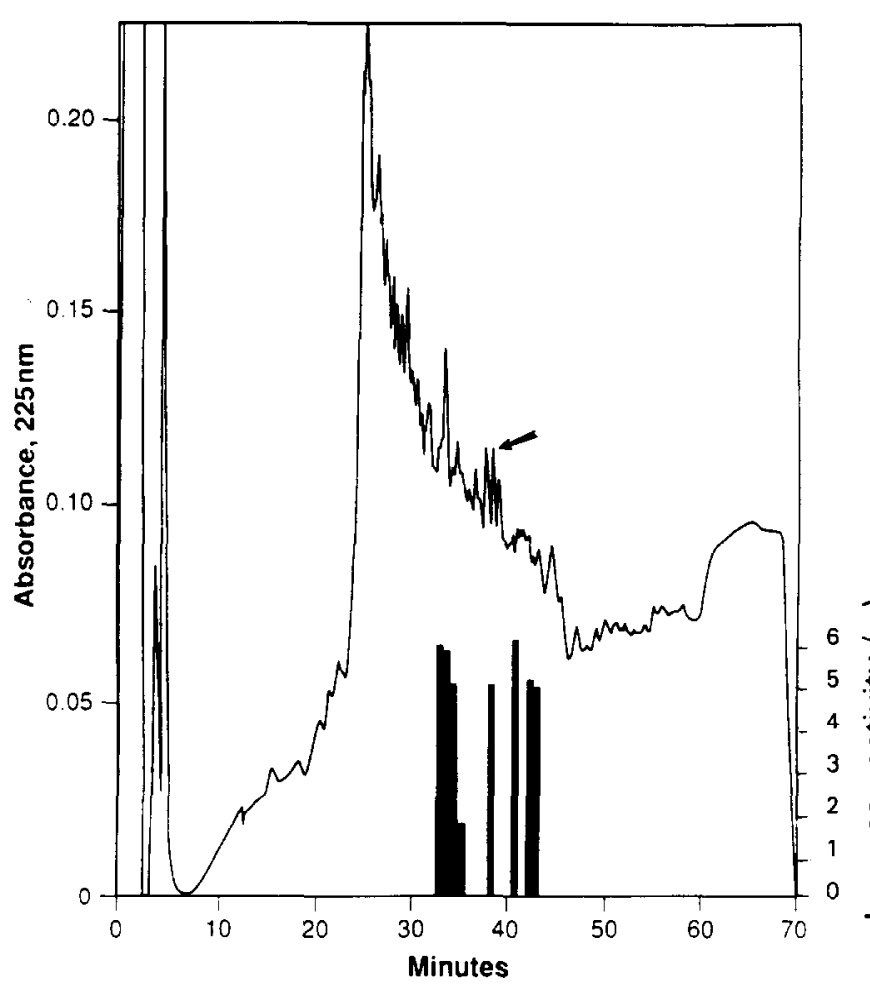

FIG. 2. PLRPS column profile. Separation of Polysulfoethyl aspartamide column fractions $60-64$ on PLRPS (100 $\AA$ ) column. Buffer $A$ was $0.1 \%$ TFA in water. Buffer $B$ was $0.1 \%$ TFA in acetonitrile. The gradient was 0 to $40 \%$ in $60 \mathrm{~min}$. The flow rate was $0.7 \mathrm{ml} / \mathrm{min}$. Fivemicroliter aliquots were analyzed. An arrow indicates the PLRPS fraction (No. 56) containing immunoreactive material identified as PheAspAspTyrGlyHisMetArgPheNH . $_{2}$

the in situ hybridization of adult head tissue (8) indicate that dsk RNA is an abundant head transcript. The observation that both drosulfakinin and cholecystokinin are abundant brain transcripts provides further evidence suggesting that drosulfakinin is a Drosophila CCK homologue.

Immunohistochemical localization of Drosophila DSK peptides. Sequence-specific DSK-specific antibody was used to localize DSK-immunoreactive material present in the Drosophila larval central nervous system. The larval nervous system consists of two paired brain lobes and the ventral ganglion. The ventral ganglion is composed of the subesophageal ganglion which is most anterior, followed by the three thoracic ganglia, and then by the seven abdominal ganglia. The description of the cell identity and number is based on whole mounts processed according to the immunofluorescence technique of White et al. (11). Immunofluorescence representing DSK-specific expression was observed in the larval brain lobes in bilaterally symmetric cells identified as the MP1 medial neurosecretory cells (Fig. 4A) and projections that extend from the cell bodies down the ventral ganglion and anterior into the brain lobes (Fig. 4B). The projections from the medial neurosecretory cell extending down the length of
TABLE 1

Automated Edman Sequencing Amino Acid Yields of Drosophila DSK-I Peptide at Each Step

PheAspAspTyrGlyHisMetArgPheNH ${ }_{2}$

\begin{tabular}{ccc} 
Cycle number & Amino acid residue assignment & Picomoles \\
\hline 1 & Phe & 24 \\
2 & Asp & 30 \\
3 & Asp & 25 \\
4 & Tyr & 16 \\
5 & Gly & 19 \\
6 & His & 1.7 \\
7 & Met & 14 \\
8 & Arg & 7.2 \\
9 & Phe & 3.8 \\
10 & - & - \\
\hline
\end{tabular}

the ventral ganglion indicate that the DSK peptides may function at positions some distance from the site of production. Projections to the abdominal ganglia are consistent with drosulfakinin peptides being cholecystokinin homologues due to the presence of CCK-immunoreactive neurons in the vertebrate gut.

Control studies indicate that the immunofluorescence is DSK-specific expression since preabsorption of the sequence-specific antibody with DSK-I completely abolished all signal (data not shown), while after preabsorntion of the antibody with FMRFamide or CCK the same
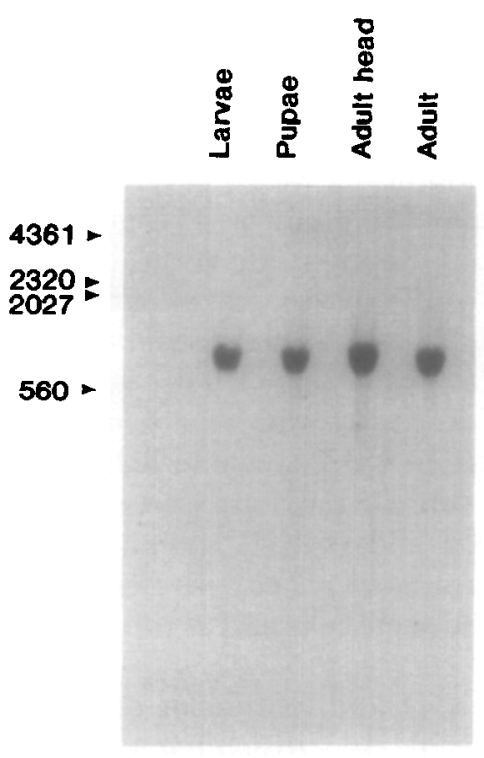

FIG. 3. Northern blot analysis of Drosophila dsk transcript. Poly(A) ${ }^{+}$RNA (10 $\left.\mu \mathrm{g}\right)$ from third instar larvae, pupae, adult whole body, and adult head were hybridized to ${ }^{32} \mathrm{P}$-labeled nick-translated dsk DNA fragment containing DSK peptides. Molecular size standards are indicated in base pairs. The blot was probed with a ribosomal protein DNA clone (rp49) from M. Rosbash (Brandeis) as a control for equal amounts of RNA present in each lane (data not shown). 


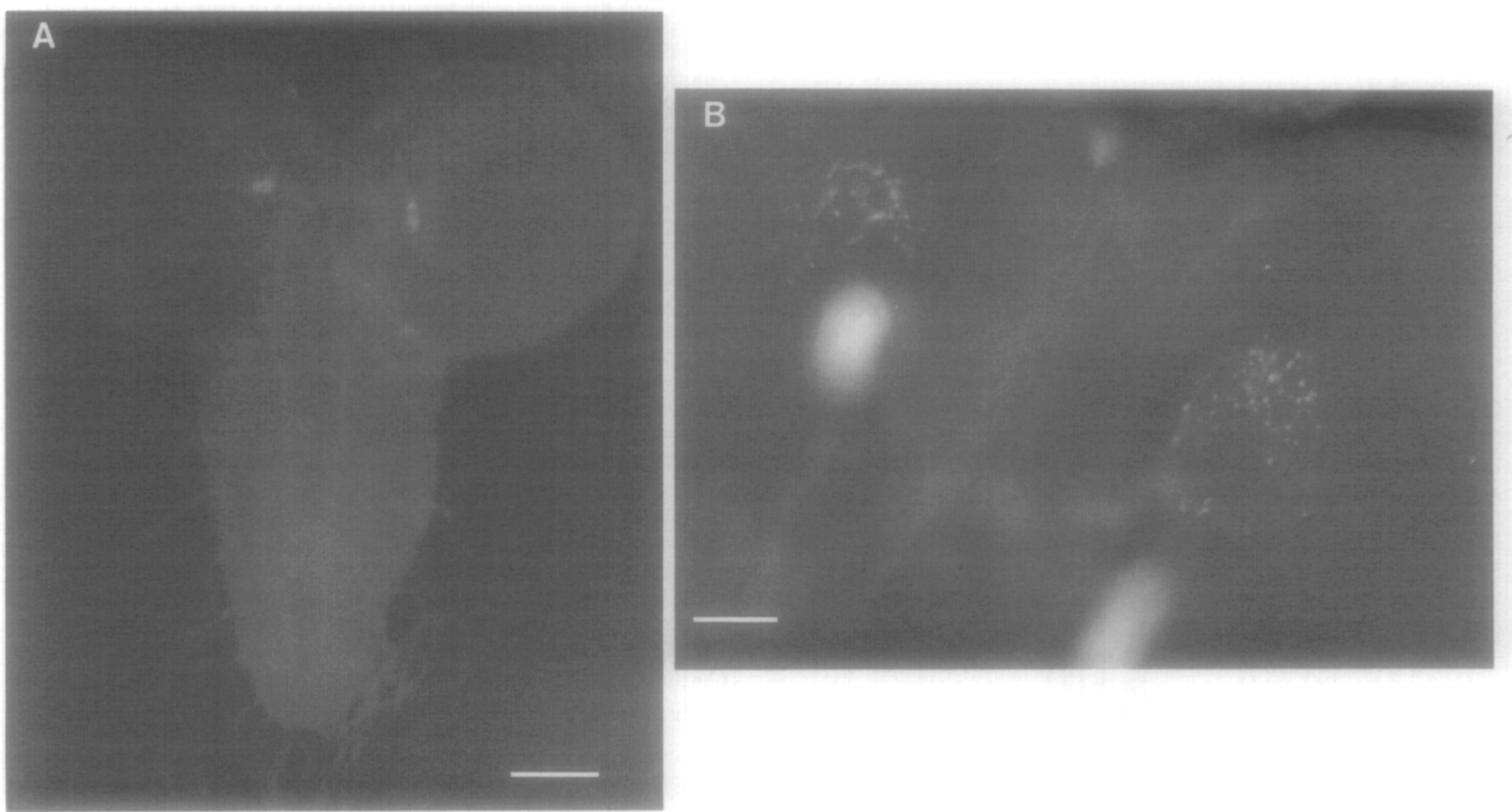

FIG. 4. Expression of DSK peptides in a whole mount larval brain preparation. Third instar brains were dissected and incubated with sequence-specific antisera against DSK-I and then incubated with FITC-labeled anti-rabbit antibody. (A) A whole mount preparation of a third instar larval central nervous system. Fluorescence is observed from the MP1 medial neurosecretory cells and projections extending down the ventral ganglion. Bar represents $50 \mu \mathrm{m}$. (B) A more dorsal plane of focus of the same preparation at a higher magnification illustrates that projections extend anteriorly from the MP1 cells. The MP1 cells are out of focus and appear as blurred images posterior to the projections. In addition, less intense signal is observed from anterior neurosecretory cells. Bar represents $10 \mu \mathrm{m}$.

pattern and intensity of fluorescence were observed. Larval preparations incubated with either first or second antibody alone resulted in no observable fluorescence.

Since DSK-II is a five-amino acid N-terminal extension of the DSK-I amino acid sequence, it is important to consider the sequence relatedness of DSK peptides when interpreting the immunolocalization data. The sequencespecific DSK antibody recognizes both DSK-I and DSKII and the fluorescent signals observed in these studies could be due to either one or both of the DSK peptides. An antibody directed toward the five-amino acid N-terminal sequence of DSK-II would help to distinguish between DSK-I and DSK-II. Antiserum that distinguishes between DSK-I and DSK-II should provide the opportunity to determine whether both DSK-I and DSK-II are processed in the same cells and at the same developmental stages.

Chin et al. (12) and Schneider et al. (13) have used antibodies specific to Drosophila proFMRFamide and DPKQDFMRFamide to study FMRFamide expression. Since the FMRFamide-specific antibodies recognize neurons present in the thoracic ganglia and not in the brain, the cells that produce FMRFamide peptides are different from those expressing DSK peptides. The unique distribution of the cells containing abundant DSK-immuno- reactive material and the high level of expression of the dsk transcript throughout the various developmental stages support the hypothesis that DSK peptides are important to neural function. The well-defined and specific nature of the expression of these two structurally related neural peptide families provides a unique opportunity for studying neural peptide expression and function utilizing molecular genetic techniques in Drosophila.

\section{ACKNOWLEDGMENTS}

The author thanks P. C. Andrews, Ph.D. (Director, The University of Michigan Medical School Protein Structure Facility), for sequence analysis and Dr. K. White (Brandeis) and Dr. L. Restifo for their skill and patience in teaching the technique of immunohistochemical localization. The author appreciates the time given and comments provided by J. E. Hoover during the early morning conversations that were both stimulating and insightful. This work was supported by National Science Foundation Grant BNS90906237 to R.N.

\section{REFERENCES}

1. Krieger, D. (1983). Brain peptides: What, where, and why? Science 222: $975-985$.

2. Vanderhaeghen, J-J., J. C. Signeau, and W. Gepts (1975). New peptide in'the vertebrate CNS reacting with antigastrin antibodies. Nature 25 7: 604--605. 
3. Montigny, C. (1989). Cholecystokinin tetrapeptide induces paniclike attacks in healthy volunteers. Arch. Gen. Psychiatry 46: 511 517.

4. Crawley, J. (1991). Cholecystokinin-dopamine interactions. Trends Pharmacol. 12: 232-236.

5. Nachman, R. J., G. M. Holman, W. F. Haddon, and N. Ling (1986a). Leucosulfakinin, sulfated insect neuropeptide with homology to gastrin and cholecystokinin. Science 234: 71-73.

6. Nachman, R. J., G. M. Holman, B. J. Cook, W. F. Haddon, and N. Ling (1986b). Leucosulfakinin-II, a blocked sulfated insect neuropeptide with homology to cholecystokinin and gastrin. Biochem. Biophys. Res. Commun. 140: 357-364.

7. Nichols, R. (1987). Isolation of a vertebrate neuropeptide homologue present in Drosophila melanogaster. In Molecular Neurobiology of Drosophila (B. Ganetsky and J. Hall, Eds.), p. 25. Cold Spring Harbor Laboratory Press, Cold Spring Harbor, NY.

8. Nichols, R., S. A. Schneuwly, and J. E. Dixon (1988). Identification and characterization of a Drosophila homologue to the vertebrate neuropeptide cholecystokinin. J. Biol. Chem. 263: 12,167-12,170.

9. Loh, Y. P., M. J. Brownstein, and H. Gainer (1984). Proteolysis in neuropeptide processing and other neural functions. Annu. Rev. Neurosci. 7: 189-222.

10. Wold, F. (1981). In vivo chemical modification of proteins (posttranslational modification). Annu. Rev. Biochem. 50: 783-814.

11. White, K., T. Hurteau, and P. Punsal (1986). NeuropeptideFMRFamide-like immunureactivity in Drosophila: Development and distribution. J. Comp. Neurol. 247: 430-438.
12. Chin, A. C., E. R. Reynolds, and R. H. Scheller (1991). Organization and expression of the Drosophila FMRFamide-related prohormone gene. DNA Cell Biol. 9: 263-271.

13. Schneider, L. E., M. A. O'Brien, and P. H. Taghert (1991). In situ hybridization analysis of the FMRFamide neuropeptide gene in Drosophila. I. Restricted expression in embryonic and larval stages. J. Comp. Neurol. 304: 608-622.

14. Bauminger, $S$., and $M$. Wilchek (1980). The use of carbodiimides in the preparation of immunizing conjugates. In Methods in Enzymology (H. Van Vunakis and J. J. Langone, Eds.), Vol. 70, pp. 151-159. Academic Press, New York.

15. Andrews, P. C. (1987). A dot-blot immunoassay method for small peptides. In Proceedings 1st Protein Society Symposium, Abstract 78.

16. Markwell, M. A. K. (1982). A new solid-state reagent to iodinate proteins. 1. Conditions for the efficient labeling of antiserum. Anal. Biochem. 125: 427-432.

17. Harlow, E., and D. Lane (1989). Detection and quantitating antigens using competition assays-variation II, $S$. aureus. In Antibodies: A Laboratory Manual, pp. 588-589. Cold Spring Harbor Press, Cold Spring Harbor, New York.

18. Alpert, A. J., and P. C. Andrews (1988). Cation-exchange chromatography of peptides in poly(2-sulfoethyl aspartamide)-silica. J. Chromatogr. 443: 85-86.

19. Chirgwin, J. M., A. E. Przybyla, R. J. MacDonald, and W. J. Rutter (1979). Isolation of biologically active ribonucleic acid from sources enriched in ribonuclease. Biochemistry 18: 5294-5299.

20. Aviv, H., and P. Leder (1972). Purification of biologically active globin messenger RNA by chromatography on oligothymidilic acidcellulose. Proc. Natl. Acad. Sci. 69: 1308-1412. 